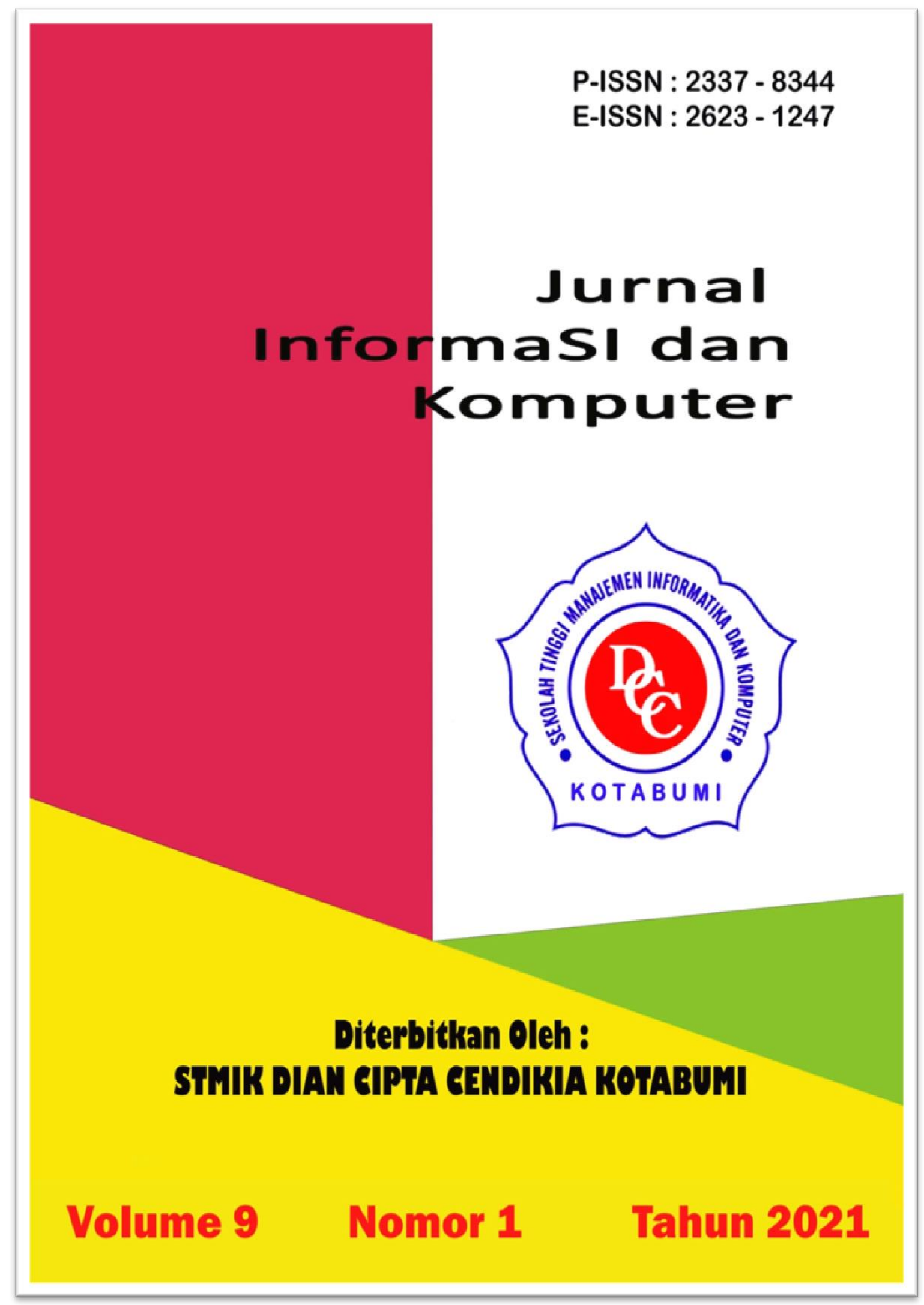




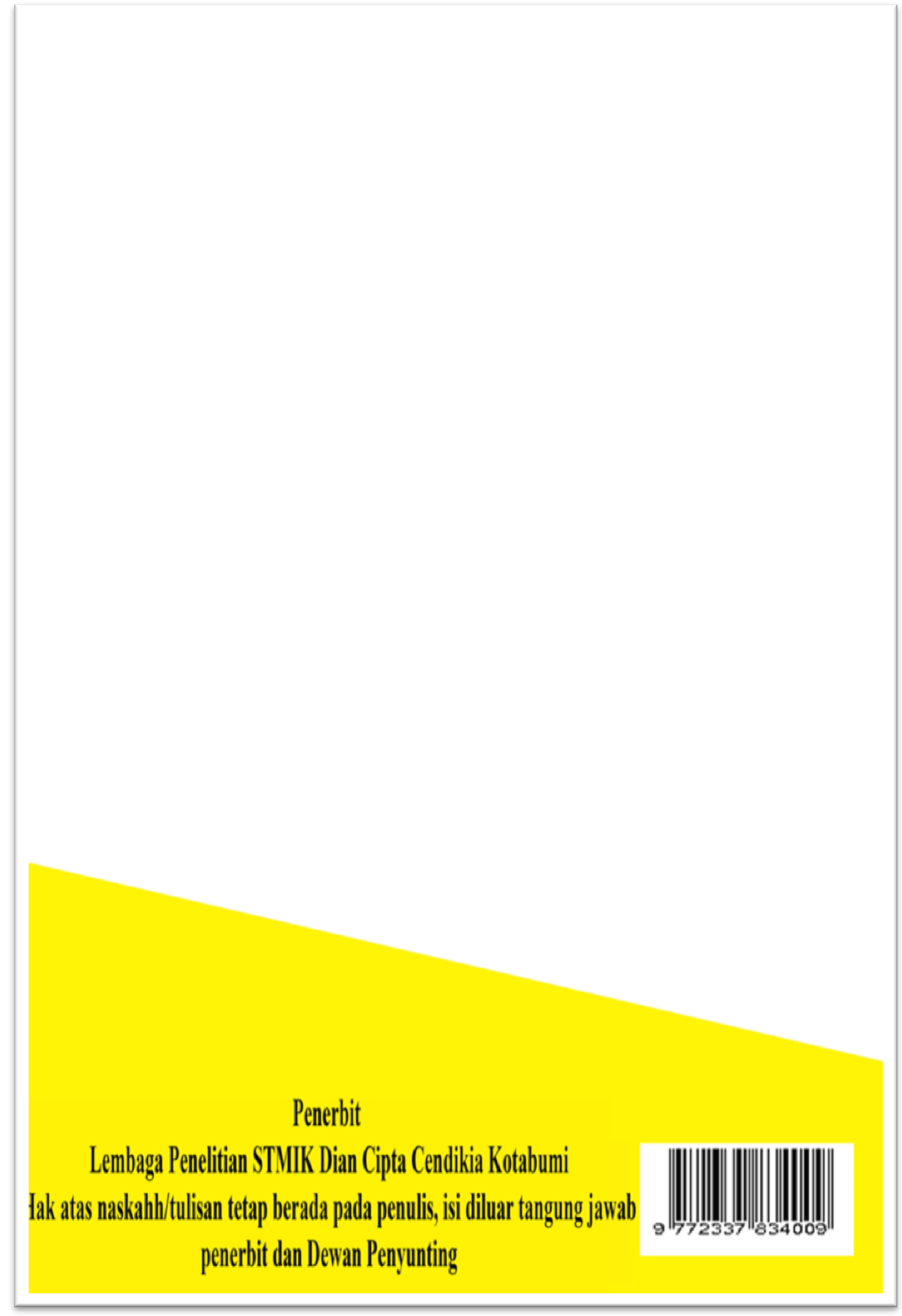




\section{JURNAL INFORMASI DAN KOMPUTER}

Volume 9 Nomor 1 Oktober 2021

Jurnal Informasi dan Komputer merupakan Sarana informasi ilmu pengetahuan, Tekhnologi dan Komunikasi yang berupa hasil penelitian, tulisan ilmiah, Ataupun studi pustaka. Jurnal ini terbit dua kali setahun pada bulan April dan Oktober. Berisi hasil penelitian ilmiah di bidang informatika yang bertujuan untuk menghubungkan adanya kesenjangan antar kemajuan teknologi dan hasil penelitian. Jurnal ini di terbitkan pertama kali pada tahun 2013.

\section{Penanggung Jawab:}

Ketua STMIK Dian Cipta Cendikia

Kotabumi

\section{Pembina:}

Ketua STMIK Dian Cipta Cendikia

Kotabumi

Ketua Lembaga Penelitian STMIK Dian

Cipta Cendikia Kotabumi

\section{Pimpinan Redaksi}

Dwi Marisa Efendi,.S.Kom.,M.Ti

\section{Redaksi pelaksana}

Rustam,.S.Kom,.M.Ti (STMIK Dian

Cipta Cendikia Kotabumi)

Nurmayanti M.Kom (STMIK Dian

Cipta Cendikia Kotabumi)

Sukatmi,.S.Kom., M.Kom (AMIK DCC

Bandar Lampung)

Sampurna Dadi Riskiono,M.Kom

(Universitas Teknokrat Indonesia)

Ifo Wahyu

Pratama,S.Kom.,M.Ti(AMIK MASTER

Lampung)
Merri Parida.,M.Kom (STMIK Dian

Cipta Cendikia Kotabumi)

Amarudin,S.Kom.,M.Eng (Universitas

Teknokrat Indonesia)

Didi Susianto.,S.T.,M.Kom (AMIK DCC

Bandar Lampung)

Alhibarsyah.,S.T.,M.Kom (Stmik Tunas

Bangsa Bandar Lampung)

Kemal Farouq Mauladi .,S.Kom.,M.Kom

(Universitas Islam Lamongan)

Agus Setiawan S.Pd.,M.Eng (Universitas

Muhammadiyah Lamongan)

Ferrly Ardhy, S.Kom., M.Ti (Universitas

Aisyah Pringsewu)

Penerbit : STMIK Dian Cipta Cendikia Kotabumi Bekerja Sama Dengan LPPM STMIK Dian Cipta Cendikia Kotabumi.

\section{Alamat Redaksi/Penerbit:}

Jl. Negara No. 3 Candimas Kotabumi

Lampung Utara

No Telpon/Fax 072423003

Email : 1ppm-stmik@dcc.ac.id

\section{Mitra Bestari}




\section{PENGANTAR REDAKSI}

Puji syukur dipanjatkan kehadirat Tuhan Yang Maha Esa, atas karunia dan limpahan rahmatnya Jurnal Informasi dan komputer (JIK) STMIK Dian Cipta Cendikia Kotabumi ini dapat terwujud, sehinga dapat di terbit 2 (dua) kali dalam setahun ini merupakan suatu wadah untuk penyebar luasan hasil-hasil penelitian, studi pustaka, karya ilmiah yang berkaitan dengan Informatika dan Komputer khususnya bagi dosen-dosen STMIK Dian Cipta Cendikia Kotabumi serta umumnya para cendikiawan, praktisi, peneliti ilmu Informatika dan Komputer.

Harapan dengan diterbitkannya Jurnal Informasi dan Komputer (JIK) ini sebagai salah satu bentuk sumbangan pemikiran dalam pengembangan ilmu informatika dan komputer yang berkaitan dengan kajian-kajian di bidang tekhnologi informatik, Komunikasi Data dan Jaringan Komputer, perancangan dan Rekayasa Perangkat Lunak, serta ilmu-ilmu yang terkait dengan bidang Informatika dan Komputer lainnya.

Berkenaan dengan harapan tersebut, kepada para peneliti, dosen dan praktisi yang memiliki hasil-hasil penelitian, kajian pustaka, karya ilmiah dalam bidang tersebut diatas, dengan bangga redaksi Jurnal Informatika dan Komputer (JIK) menerima naskah ringkasan untuk dimuat pada jurnal Informasi dan Komputer (JIK) STMIK Dian Cipta Cendikia Kotabumi dengan berpedoman pada penulisan naskah jurnal sebagaimana dilampirkan pada halaman belakang (Bagian kulit dalam) buku jurnal ini.

Mutu dari suatu jurnal ilmiah tidak hanya ditentukan oleh para pengelolanya saja, tetapi para penulis dan pembaca jualah yang mempunyai peranan besar dalam meningkatkan mutu jurnal Informatika dan Komputer ini. Merujuk pada realita ini kamu sangat mengharapkan peran aktif dari peneliti untuk bersama-sama menjaga dan memelihara keberlangsungan dari jurnal Informatika dan Komputer STMIK Dian Cipta Cendikia Kotabumi ini. Yang juga tidak kalah pentingnya dari partisipasi tersebut diatas, adalah saran dan kritik yang membangun dari pembaca yang budiman agar kiranya dapat disampaikan langsung kepada redaksi JIK. Saran dan kritik yang membangun akan dijadikan masukan dan pertimbangan yang sangat berarti guna peningkatan mutu dan kualitas Jurnal Informatika dan Komputer STMIK Dian Cipta Cendikia Kotabumi.

Tak lupa diucapkan terima kasih yang tak terhingga atas perhatian dan kerjasama dari semua pihak yang tak dapat disebutkan satu persatu hingga dapat diterbitkan nya Jurnal Informasi dan Komputer (JIK) STMIK Dian Cipta Cendikia Kotabumi. Semoga apa yang telah diperbuat untuk kebaikan akan menjadi amal ibadah, amin.

Kotabumi, 25 April 2021

Dewan Redaksi 


\section{JURNAL INFORMASI DAN KOMPUTER}

VOL. 9 NO. 1 THN. 2021

\section{DAFTAR ISI}

Halaman

Implementasi Framework ITIL 3 Pada Aplikasi Pelayanan Pelanggan Terpadu PT. PLN (PERSERO)

Wilayah Kotabumi

Ferly Ardhy, Dwi Marisa Efendi, Mitha Franciska, Nur Aminudin, Rustam,

Abdullah Umar Faqih Al Ikhsani

(Universitas Aisyah Pringewu, STMIK Dian Cipta Cendikia Kotabumi)

$01-06$

Penerapan Metode Naive Bayes Dalam Menentukan Pengaruh Keaktifan Mahasiswa Berrorganisasi

Terhadap Presentasi Belajar

Debby Febriani R Saragih, Heru Satria Tambunan, Jaya Tata Hardinata

(STIKOM Tunas Bangsa Pematangsiantar Indonesia)

Penerapan Data Mining Untuk Prediksi Penjualan Pupuk Dengan Metode Algoritma Apriori

Dwi Marisa Efendi, Sidik Rahmatullah, Asep Afandi, Pakarti Riswanto, Nurmayanti

(STMIK Dian Cipta Cendikia Kotabumi)

Sistem Informasi Pelayanan Administrasi Surat Pengantar Berbasis Website Dengan Framework Codeigniter Guna

Meningkatkan Kualitas Pelayanan Pada Desa Tambaksari Kidul Kabupaten Banyumas

Endang Setyawati1, Suyudi, Foustino Asprilla Gunantara, Hadion Wijoyo

(STIKOM Yos Sudarso Purwokerto, STMIK Dharmapala Riau)

Implementasi Algoritma Naive Bayes Untuk Menentukan Tingkat Kedisiplinan Siswa

Sidik Rahmatullah, Iko Prastiyo

(STMIK Dian Cipta Cendikia Kotabumi)

Pemanfaatan Framework Codeigniter Untuk Membangun Aplikasi Display Produk Di Alfamart Rajabasa Yuli Syafitri1, Yudi Dwi Pramudya, Muhammad Rasid

(AMIK Dian Cipta Cendikia, STMIK Tunas Bangsa)

Perbandingan Metode Nearest Neighbor, Ward Dan K-Means Dalam Menentukan Cluster Data Kinerja

Kantor Unit Bank Abc

Bambang Suprapto, Henry Simanjuntak, Sulasminarti

(AMIK Dian Cipta Cendikia Pringsewu)

“Aplikasi Computer Basic Test (Cbt) Pada Smk Ma’arif Sukoharjo Kec. Pringsewu Kab. Pringsewu

Berbasis Web"

Rima Mawarni, Dewi Triyanti. Ardiansyah

(STMIK Dian Cipta Cendikia Kotabumi, AMIK Dian Cipta Cendikia Pringsewu) 
Pengembangan Aplikasi Pencarian Guru Privat Editing Video Berbasis Android

Nurhasan Nugroho, Riduwan Napianto, Imam Ahmad, Wahyu Ariya Saputra

(Universitas Bina Bangsa, Universitas Teknokrat Indonesia)

Sistem Penilaian Kinerja Karyawan Dengan Menggunakan Metode Simple Additive Weighting (Saw)

Darsin, Desi Triyana

(Universitas Megou Pak Tulang Bawang).

Aplikasi Belajar Dasar-Dasar Bahasa Isyarat Berbasis Android

Ngajiyanto, Sigit Mintoro, Melpin Aprido Jenius,

(STMIK Dian Cipta Cendikia kotabumi) 


\title{
SISTEM INFORMASI PELAYANAN ADMINISTRASI SURAT PENGANTAR BERBASIS WEBSITE DENGAN FRAMEWORK CODEIGNITER GUNA MENINGKATKAN KUALITAS PELAYANAN PADA DESA TAMBAKSARI KIDUL KABUPATEN BANYUMAS
}

\author{
Endang Setyawati ${ }^{1}{ }$ Suyudi $^{2}$, Foustino Asprilla Gunantara ${ }^{3}$, Hadion Wijoyo ${ }^{4}$ \\ STIKOM Yos Sudarso Purwokerto ${ }^{123}$, STMIK Dharmapala Riau ${ }^{4}$ \\ E-mail : endang.setiawati@stikomyos.ac.id, suyudi.pwt@stikomyos.ac.id,fa.gunantara@gmail.com, \\ Hadion.wijoyo@lecturer.stmikdharmapalariau.ac.id
}

\begin{abstract}
ABSTRAK
Di era otonomi daerah, desa merupakan bagian yang sangat penting dalam menentukan keberhasilan pembangunan dan bersetuhan langsung dengan masyarakat terutama dalam pelayanan publik. Sejalan dengan agenda reformasi dari Kementerian Pemberdayaan Aparatur Negera dan Reformasi Birokrasi bahwa setiap individu dan organisasi dituntut untuk mengembangkan diri guna meningkatkan pelayanan masyarakat. Pengelolaan administrasi dan arsip yang konvensional harus diubah menjadi berbasis sistem dan digital. Tambaksari Kidul adalah sebuah Desa yang terletak di Kecamatan Kembaran, Banyumas, Jawa Tengah. Sebuah Desa tentunya memiliki sebuah Kantor Balai Desa yang berfungsi untuk melakukan pencatatan dan pengolahan data penduduk desanya. Pelayanan administrasi yang mereka layani salah satunya adalah merealisasi surat pengantar yang di bawa warga desa. Namun dalam proses pembuatan surat pengantar, kerap kali warga merasa kesulitan di karenakan sulit untuk bertemu dengan ketua RT dan ketua RW untuk meminta tanda tangan. Sehingga dalam pembuatan surat pengantar membutuhkan waktu beberapa hari, hal ini tentu saja membuat warga merasa pembuatan surat pengantar memakan waktu dan tenaga yang cukup lama. Maka dari itu dibutuhkan sebuah sistem informasi pelayanan administrasi surat pengantar berbasis website dengan framework codeigniter guna meningkatkan kualitas pelayanan pada desa Tambaksari Kidul Kabupaten Banyumas, yang di harapkan dapat membantu warga dalam melakukan proses pengajuan permohonan surat pengantar kapan saja dan dimana saja tanpa harus memakan waktu dan tenaga yang cukup lama.
\end{abstract}

Kata Kunci : Sistem Informasi Pelayanan Administrasi, Desa, Surat Pengantar, Website, Framework Codeigniter.

\begin{abstract}
In the era of regional autonomy, villages play a very important part of determining the success of development and directly having a contact with the community, especially in public services. In line with the reform agenda of the Ministry of

State Apparatus Empowerment and Bureaucratic Reform, that every individual and organization is required to develop themselves in order to improve community services. Conventional administrative and archive management shall be changed to digital system based. Tambaksari Kidul is a village located in Kembaran District, Banyumas, Central Java. A village certainly has a Village Hall Office which functions to record and process data on the population of the village. One of the administrative services that they provide is the approval of cover letters that the villagers bring. However, in the process of
\end{abstract}


making a cover letter, residents often facing difficulties to get the signatures of the $R T$ and $R W$ heads. Hence, it will take a few days to make it, as a result the residents think it is time and energy consuming. Therefore, a website-based for cover letter administration service information system with a codeigniter framework is needed to improve the quality of service in Tambaksari Kidul village, Banyumas Regency, which is expected to help residents in the process of submitting a cover letter application anytime and anywhere without consuming too much time and energy.

Keywords : Administration Service Information System, Village, Cover Letter, Website, Codeigniter Framework.

\section{PENDAHULUAN}

\subsection{Latar Belakang}

Pemerintah Desa ialah penyelenggaraan urusan pemerintahan dan kepentingan masyarakat setempat dalam sistem pemerintah Negara Kesatuan Republik

Indonesia. Hakekatnya sebagai pemenuhan kebutuhan dasar masyarakatnya, atau sebagai unsur pemerintah yang melayani masyarakatnya. Sehingga Pemerintah Desa memiliki urusan yang dijadikan tugas bagi pemerintahan, seperti urusan tata pemerintahan, urusan pemberdayaan masyarakat desa, urusan kesejahteraan masyarakat dan urusan ketertiban lingkungan[1]

Di era otonomi daerah, desa merupakan bagian yang sangat penting dalam menentukan keberhasilan pembangunan dan bersetuhan langsung dengan masyarakat terutama dalam pelayanan publik. Sejalan dengan agenda reformasi dari Kementerian Pemberdayaan Aparatur Negera dan Reformasi Birokrasi bahwa setiap individu dan organisasi dituntut untuk mengembangkan diri guna meningkatkan pelayanan masyarakat. Pengelolaan administrasi dan arsip yang konvensional harus diubah menjadi berbasis sistem dan digital[2].

Tambaksari Kidul adalah sebuah Desa yang terletak di Kecamatan Kembaran, Banyumas, Jawa Tengah.

Sebuah Desa tentunya memiliki sebuah Kantor Balai Desa yang berfungsi untuk melakukan pencatatan dan pengolahan data penduduk desanya. Pelayanan administrasi yang mereka layani salah satunya adalah merealisasi surat pengantar yang di bawa warga desa. Namun dalam proses pembuatan surat pengantar, kerap kali warga merasa kesulitan di karenakan sulit untuk bertemu dengan ketua RT dan ketua RW untuk meminta tanda tangan. Sehingga dalam pembuatan surat pengantar membutuhkan waktu beberapa hari, hal ini tentu saja membuat warga merasa pembuatan surat pengantar memakan waktu dan tenaga yang cukup lama.

Agar proses pembuatan surat pengantar dapat dilakukan dengan mudah dan cepat, maka dari itu dibutuhkan sebuah sistem informasi pelayanan administrasi surat pengantar berbasis website dengan framework codeigniter guna meningkatkan kualitas pelayanan pada desa Tambaksari Kidul Kabupaten Banyumas, yang di harapkan dapat membantu warga dalam melakukan proses pengajuan permohonan surat pengantar kapan saja dan dimana saja tanpa harus memakan waktu dan tenaga yang cukup lama.

\subsection{Perumusan Masalah}

Bagaimana cara membangun Sistem Informasi Pelayanan Administrasi Surat Pengantar Berbasis Website Dengan Framework Codeigniter Guna Meningkatkan Kualitas Pelayanan Pada Desa Tambaksari Kidul Kabupaten Banyumas?

\subsection{Ruang Lingkup}

a. Penelitian dilakukan di Balai Desa Tambaksari Kidul yang berada di JL. Sunan Bonang, Kembaran, Dusun I, Tambaksari 
Kidul, Banyumas, Kabupaten Banyumas, Jawa Tengah.

b. Membangun Sistem informasi pelayanan administrasi surat pengantar berbasis Website dengan Framework Codeigniter pada Desa Tambaksari Kidul guna meningkatkan kualitas pelayanan.

c. Sistem informasi ini dibuat dengan menggunakan Visual Studio Code, PHP, Framework Codeigniter, Bootstrap serta Database MySQL.

d. Sistem informasi ini digunakan untuk pembuatan surat pengantar oleh Warga, Pengolahan Data Warga Desa, dan Validasi Ketua RT \& Ketua RW.

e. Sistem dibuat untuk 4 aktor yaitu Admin, Ketua RT, Ketua RW, dan Warga.

\subsection{Tujuan Penelitian}

Terbangunnya Sistem Informasi Pelayanan Administrasi Surat Pengantar Berbasis Website Dengan Framework Codeigniter Guna Meningkatkan Kualitas Pelayanan

Pada Desa Tambaksari Kidul Kabupaten Banyumas. Dengan di bangunnya sistem ini diharapkan akan membantu administrasi proses pengajuan permohonan surat pengantar secara efektif dan meningkatkan kualitas pelayanan di Desa Tambaksari kidul.

\subsection{Manfaat Penelitian}

1. Proses dalam pembuatan surat pengantar menjadi lebih efisien.

2. Proses penyampaian informasi menjadi lebih cepat dan akurat.

3. Penggunaan anggaran Desa lebih efisien.

\section{TINJAUAN PUSTAKA}

\subsection{Sistem Informasi}

Menurut (Sutabri, 2016) Kegiatan strategi dari suatu organisasi untuk dapat menyediakan kepada pihak luar tertentu dengan laporanlaporan yang diperlukan. Sistem terdiri dari komponen-komponen yang disebut blok bangunan (building block) yang terdiri dari blok masukan, blok model, blok keluaran, blok basis data dan blok kendali. Sebagai suatu sistem, keenam blok tersebut masing-masing saling berinteraksi satu dengan yang lain membetuk satu-kesatuan untuk

mencapai sasaran .

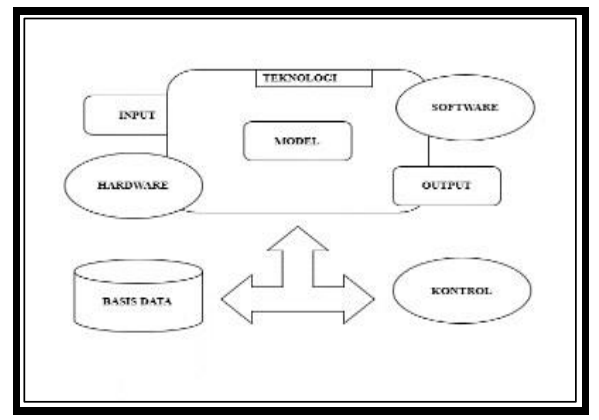

Gambar 1. Komponen Sistem Informasi (Sutabri, 2016)

\subsection{Desa}

Menurut R. Bintaro (1986), desa dapat dikatakan sebagai suatu hasil perpaduan antara kegiatan sekelompok manusia dengan lingkungannya. Hasil dari perpaduan itu ialah suatu wujud atau kenampakan di muka bumi yang ditimbulkan oleh unsur-unsur fisiografi, social, ekonomi, politik dan cultural yang saling berinteraksi antar unsur tersebut dan juga dalam hubungannya dengan daerah-daerah lain[3].

\subsection{Surat Pengantar}

Menurut Thomas Wiyasa (1992) pengertian surat pengantar yaitu: Surat pengantar adalah sarana untuk menyampaikan pernyataan atau informasi secara tertulis dari pihak yang satu ke pihak yang lain, informasi dapat berupa pemberitahuan, pernyataan laporan, pemikiran, sanggahan dan lain sebagainya. Pendapat yang berbeda di ungkapkan menurut Atmosudirdjo, S. Prajudi mengenai surat pengantar adalah sehelai kertas yang di tulis atau di ketik atas nama dalam kedudukan yang di tujukan kepada suatu alamat tertentu dan membuat suatu badan komunikasi. (1999)[4]. 


\subsection{Framework}

Framework adalah desain dan program kerangka aplikasi yang digunakan untuk menbangun aplikasiaplikasi yang sejenis. Framework memiliki banyak Pustaka tingkat tinggi yang dapat digunakan secara berulang. Umumnya framework perangkat lunak didesain secara berorientasi objek sehingga desain dan programnya tersedia sebagai class-class abstract. Framework aplikasi mendefinisikan arsitektur aplikasi sehingga penambah fungsifungsi lain dapat dilakukan dengan menambah modul-modul tanpa perlu memodifikasi kode program yang sudah ada (kecuali file-file konfigurasi) (Basuki, 2010)[5].

\subsection{Codeigniter}

Codeigniter adalah adalah sebuah framework PHP yang dapat mempercepat pengembang untuk membuat sebuah aplikasi web.

Dilengkapi banyak library dan helper yang berguna di dalamnya, tentunya mempermudah proses development

(Daqiqil Id, 2011)[5].

\subsection{Database}

Menurut (Setyawati, Sarwani, Wijoyo, \& Soeharmoko,

Database Management System (DBMS) merupakan

Sistem pemrosesan basis data dimaksudkan untuk mengatasi kelemahankelemahan yang ada pada sistem pemrosesan berkas.

\section{METODOLOGI PENELITIAN}

\subsection{Metode Pengembangan Sistem}

Pembuatan sistem dengan menggunakan metode prototipe.

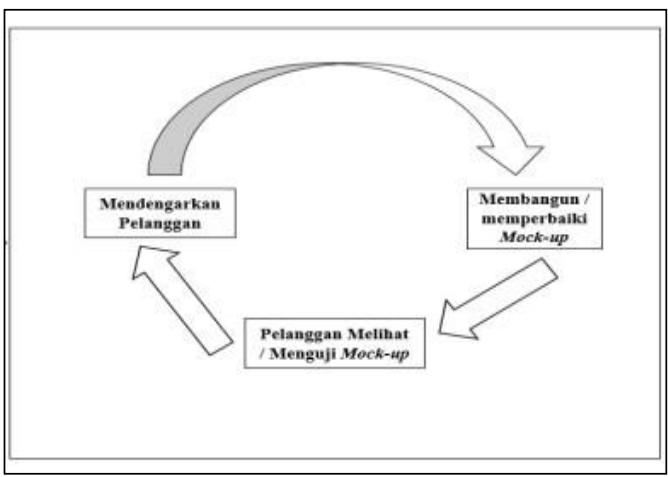

Gambar 2. Metode Prototipe (Rosa \&

Shalahudin,2016)

\subsection{Pengumpulan Kebutuhan}

Model prototipe cocok digunakan untuk menjabarkan kebutuhan pelanggan secara lebih detail karena pelanggan sering kali kesulitan menyampaikan kebutuhannya secara detail tanpa melihat gambaran yang jelas. Program prototipe biasanya menyediakan tampilan dengan simulasi alur perangkat lunak sehingga tampak seperti perangkat lunak yang sudah jadi[6].

\subsection{Desain Sistem}

Dalam tahapan proses ini yaitu pembuatan rancangan (desain) secara menyeluruh untuk tahap selajutnya yaitu dikembangkan Kembali. Pada tahap ini proses perancangan dilakukan dengan menggunakan pemodelan masalah yang menggunakan Analisa berorientasi objek dengan penggambaran diagram dalam UML. Diagaram yang dimaksud antara lain adalah diagram use case, diagram sekuen, diagram aktivitas, dsb. Berikut ini adalah diagram yang sering digunakan dalam UML menurut Rosa dan Shalahuddin : 
a.

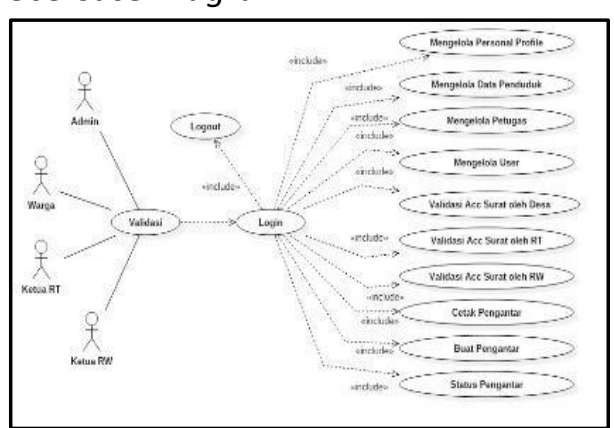

Gambar 3. Use Case Diagram Umum

Dalam sistem informasi pelayanan administrasi surat pengantar pada Desa Tambaksari Kidul terdapat 4 aktor pengguna sistem, yaitu admin(perangkat desa bagian kepengurusan surat) sebagai pengelola sistem dan manajemen sistem tersebut. Selanjutnya ada warga, disini warga dapat membuat surat pengantar. Kemudian ada ketua RT, disini ketua RT dapat memberikan validasi acc surat pengantar yang diajukan warga, setelah itu ketua RT mengarahkan ke ketua RW. Terakhir ada ketua $\mathrm{RW}$, disini ketua RW dapat memberikan validasinya terhadap acc surat pengantar yang telah di validasi ketua RT. Ketua RW kemudian mengarahkan warga untuk dapat datang ke balai desa untuk mencetak surat pengantar yang telah mereka ajukan.

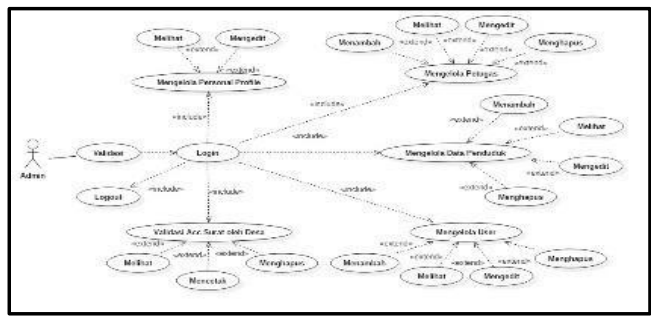

Gambar 4. Use Case Diagram Admin

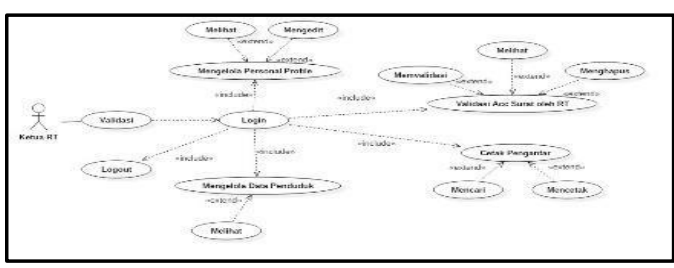

Gambar 5. Use Case Diagram Ketua RT

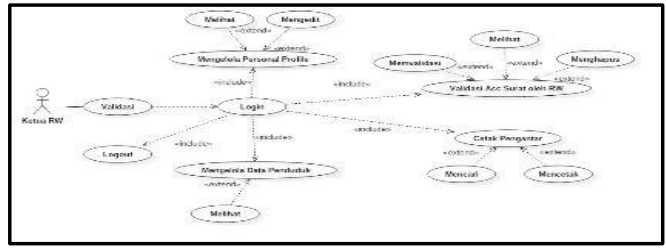

Gambar 6. Use Case Diagram Ketua RW

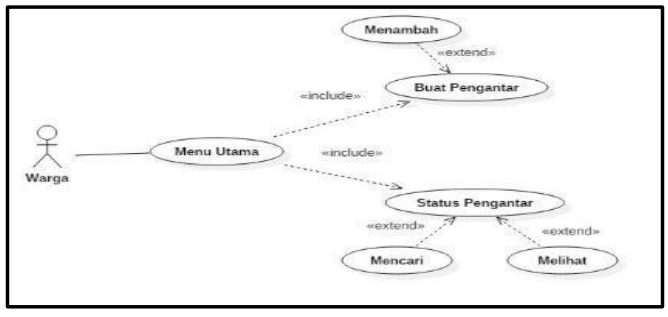

Gambar 7. Use Case Diagram Warga

b. Class Diagr am

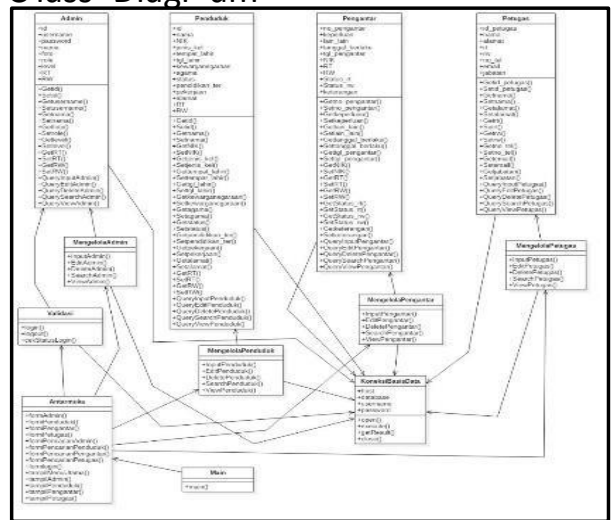

Gambar 8. Class Diagram

Gambar class diagram di atas menggambarkan struktur sistem pada sistem yang penulis bangun, yaitu Sistem Informasi Pelayanan Administrasi Surat Pengantar Berbasis Website dari segi kelaskelas yang ada. Dalam penggambaran kelas-kelas terdapat sebuah main yang merupakan kelas main. Kemudian adanya antarmuka yang merupakan sebuah kelas yang bertugas menangani tampilan. Lalu validasi, yaitu sebuah kelas yang diambil berdasarkan pendefinisian dari use case validasi. Selanjutnya ada sebuah koneksi basis data yang berperan sebagai kelas utilitas yang 
nantinya akan digunakan untuk melakukan koneksi ke basis data dan melakukan query. Terakhir, adanya kelas data-data sebagai proses untuk melakukan segala pengaksesan data dan melakukan pengelolaan yang merupakan sebuah kelas proses yang nantinya akan diambil dari pendefinisian use case.

\section{c. Activity Diagram}

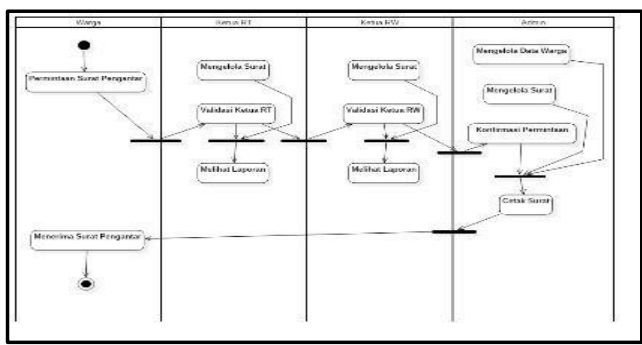

Gambar 9. Activity Diagram

Gambar diagram aktivitas diatas menggambarkan workflow (alur kerja) yang terdapat pada sistem. Aktivitas tersebut bermula dari warga. Inti dari aktivitas diagram ini adalah warga melakukan permintaan surat keterangan RT. Kemudian pihak ketua RT akan melakukan validasi surat untuk di acc, lalu surat tersebut akan dilanjutkan oleh pihak ketua RW untuk melakukan validasi surat untuk di acc. Setelah pihak rt dan rw memberikan accnya, makan surat akan di konfirmasi oleh pihak balai desa. Setelah itu warga akan datang ke balai desa untuk melakukan proses pencetakan surat keterangan yang telah mereka ajukan.

\section{HASIL DAN PEMBAHASAN}

\subsection{Hasil Pengembangan Sistem}

1) Tampilan Halaman Login

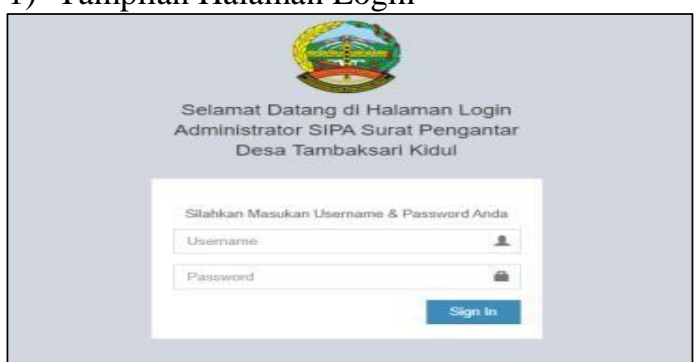

Gambar 10. Tampilan Halaman Login

2) Tampilan Halaman Utama Admin

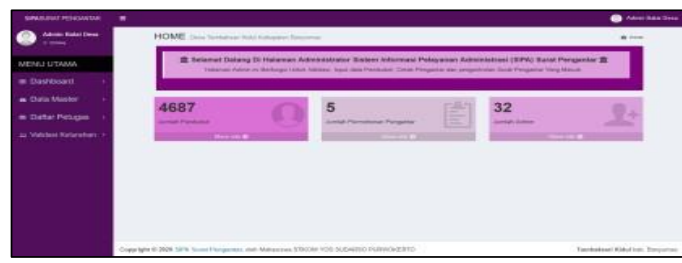

11. Tampilan

Halaman Utama Admin

3) Tampilan Input Penduduk Dengan Form

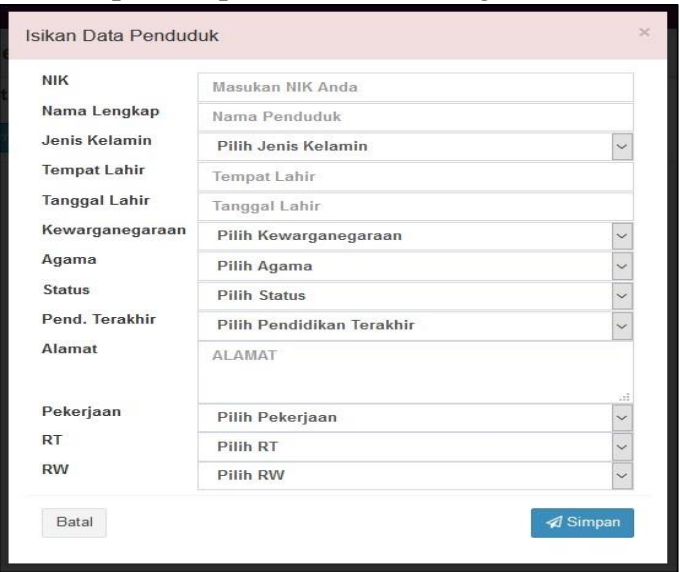

Gambar 12. Tampilan Input penduduk dengan form

4) Tampilan Input Penduduk Dengan Exel
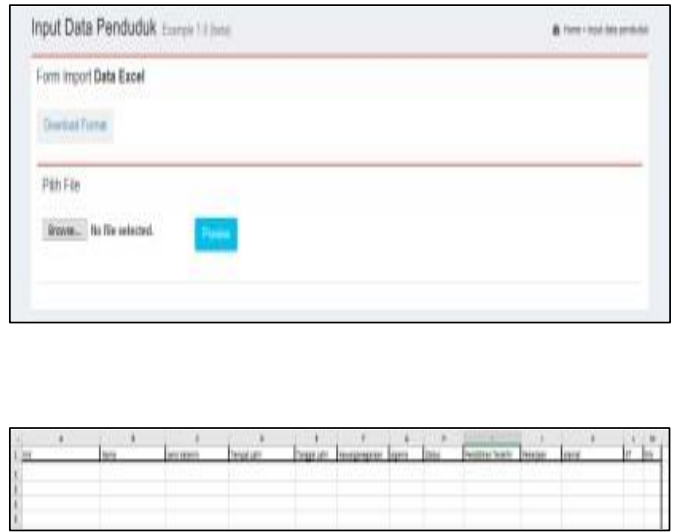

Gambar 13. Tampilan Input penduduk dengan exel

5) Tampilan Validasi Surat Pengantar Oleh Pihak Desa 


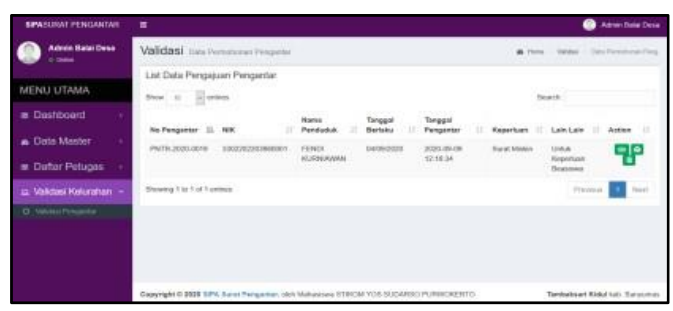

Gambar 14. Tampilan Validasi Surat Pengantar Oleh Pihak Desa

6) Tampilan Halaman Utama Ketua RT

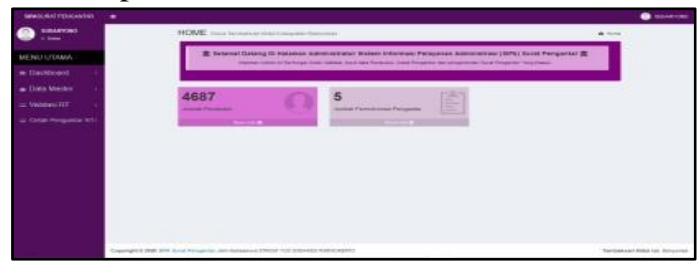

Gambar 15. Tampilan Halaman

Utama Ketua RT

7) Tampilan Validasi Surat Pengantar RT oleh Ketua RT

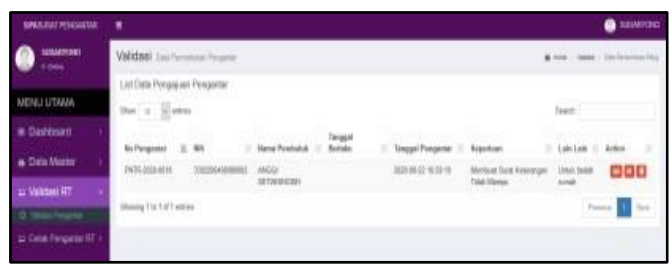

Gambar 16. Tampilan Validasi Surat Pengantar Oleh Pihak Ketua RT

8) Tampilan Halaman Utama Ketua RW

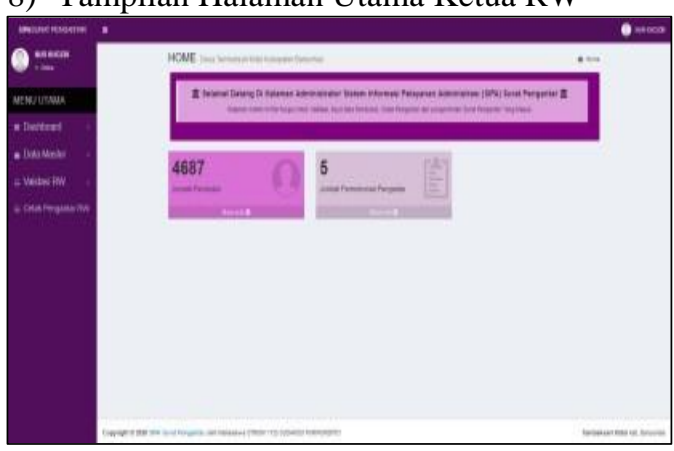

Gambar 17. Tampilan Halaman

Utama Ketua RW
9) Tampilan Validasi Surat Pengantar RT oleh Ketua RW

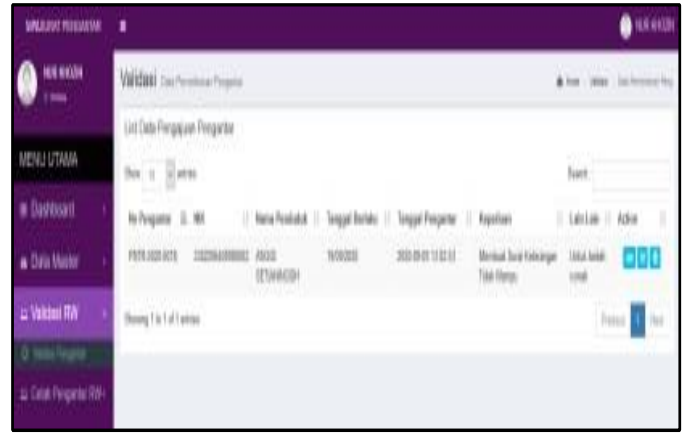

Gambar 18. Tampilan Validasi Surat Pengantar Oleh Pihak Ketua RW

\section{0) Tampilan Halaman Utama Warga}

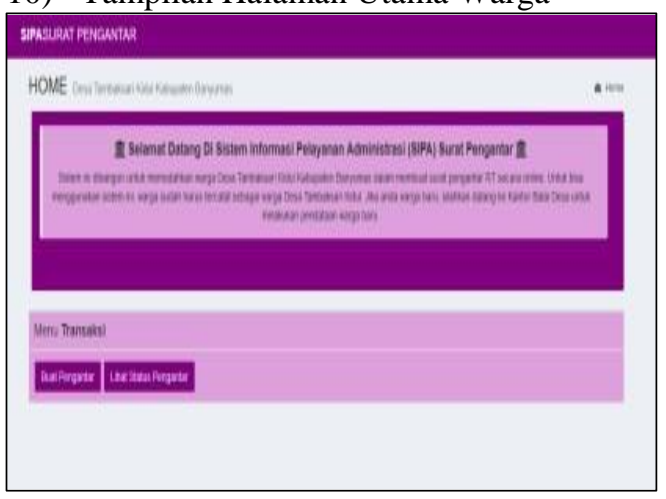

Gambar 19. Tampilan Halaman Utama Warga

11) Tampilan Pembuatan Surat Pengantar

\begin{tabular}{|l|l|}
\hline \multicolumn{2}{|l|}{ Isikan Keperluan Anda } \\
\hline $\begin{array}{l}\text { No Pengantar } \\
\text { NIK }\end{array}$ & PNTR-2020-0020 \\
\hline $\begin{array}{l}\text { Nama Lengkap } \\
\text { Keperluan } \\
\text { Lain lain }\end{array}$ & Masulan NIK Anda \\
\cline { 2 - 2 } & Mama Otomatis \\
\hline Gatala & Lain Lain \\
\hline
\end{tabular}

Gambar 20. Tampilan Pembuatan Surat Pengantar

12) Tampilan Status Surat Pengantar 


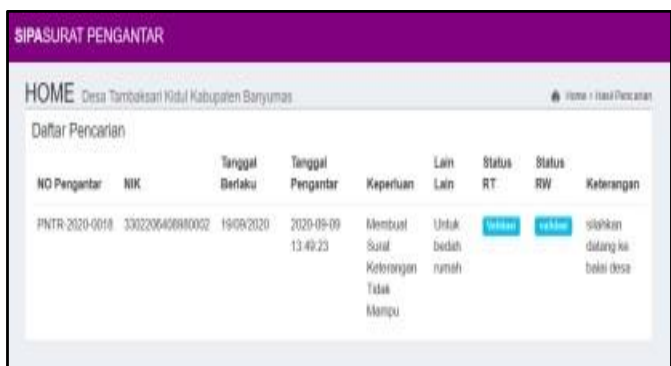

Gambar 21. Tampilan Status Surat Pengantar

13) Tampilan Surat Pengantar RT

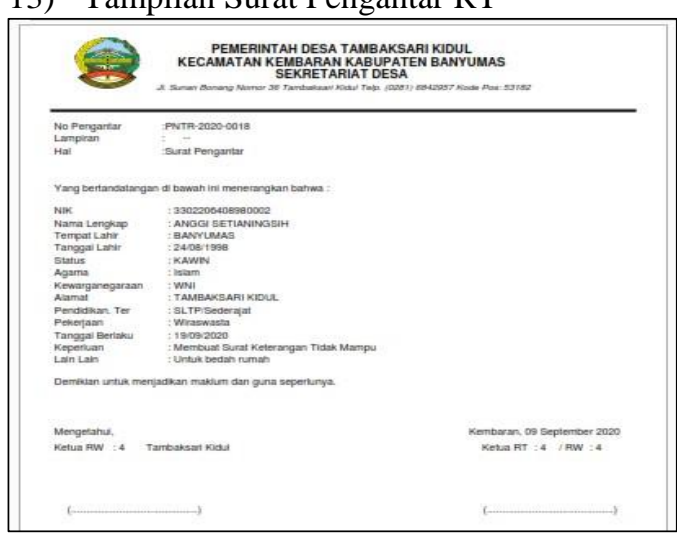

Gambar 22. Tampilan Surat Pengantar RT

14) Tampilan Surat Pengantar dari Desa

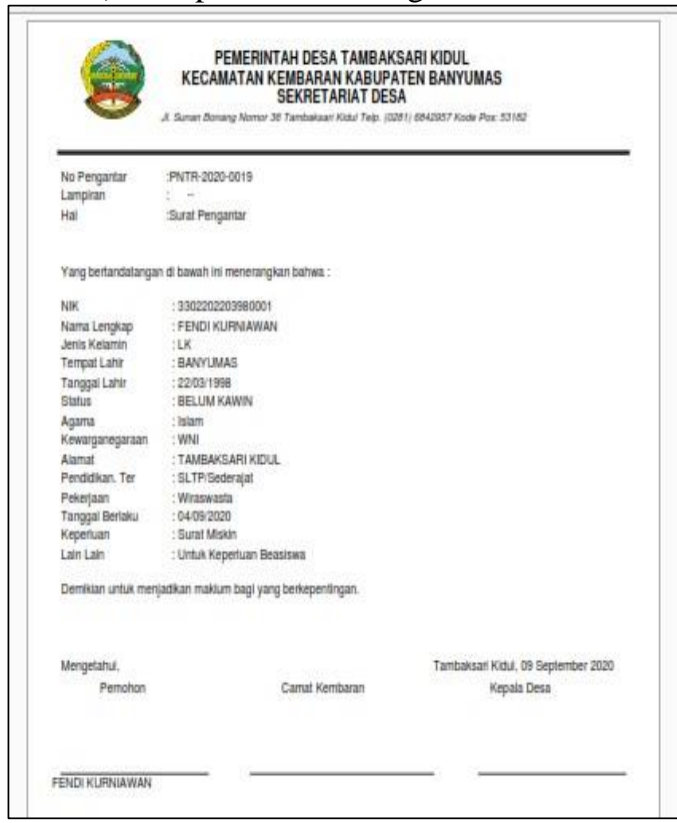

Gambar 23. Tampilan Surat Pengantar dari Desa

\subsection{Pengujian Sistem}

White Box Testing Login

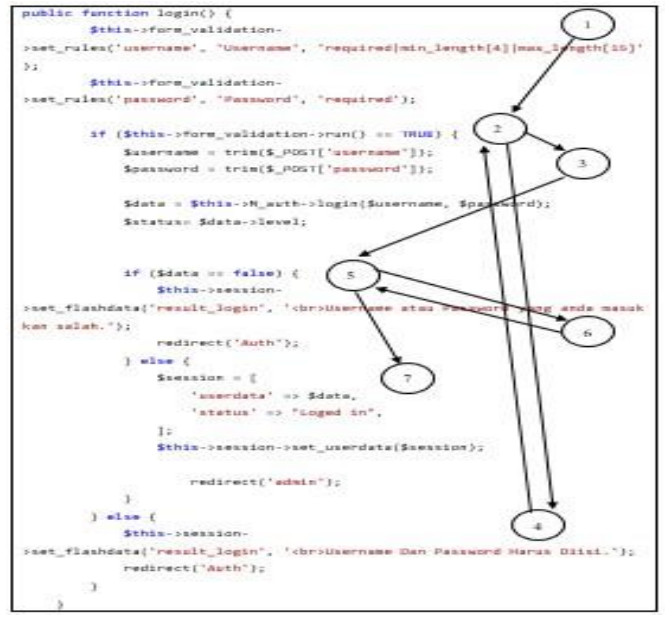

Gambar 24. White Box Testing Login

Flowgraph

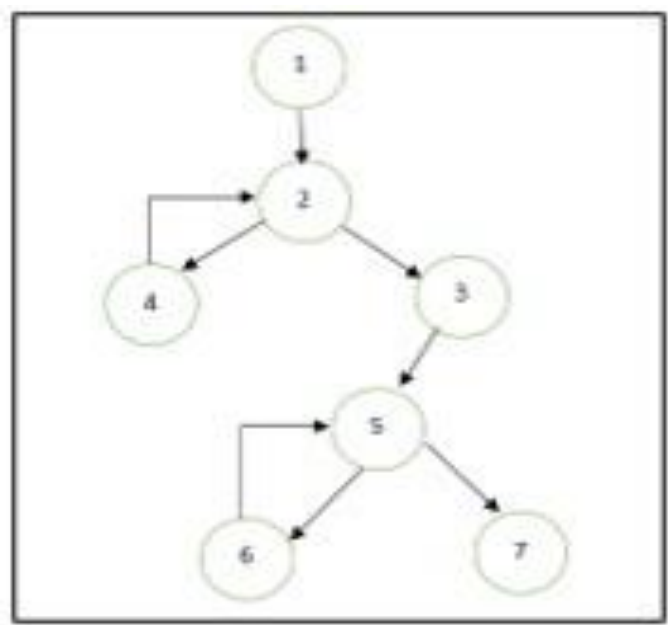

Gambar 25. Flowgraph Proses Login

Berdasarkan gambar diatas, peneliti dapat menghitung kompleksitas siklomatis dengan menggunakan rumus $\mathrm{V}(\mathrm{G})=\mathrm{E}-\mathrm{N}$ +2 . Sehingga perhitungan kompleksitas siklomatisnya adalah sebagai berikut :

$$
\begin{aligned}
& V(G)=E-N+2 \\
& V(G)=8-7+2 \\
& V(G)=3
\end{aligned}
$$

Berdasarkan alurnya, maka diperoleh independent path sebagai berikut : 
a. Jalur $1=1-2-3-5-7$

b. Jalur $2=1-2-4-2-3-5-7$

c. Jalur $3=1-2-3-5-6-5-7$

Jika semua data dimasukan dengan benar, maka jalur terpendek yang akan dilalui yaitu jalur 1 .

Black Box Testing

Tabel 1. Black Box Testing

\begin{tabular}{|c|c|c|c|c|c|}
\hline Descriptio & Test Case & Input & $\begin{array}{c}\text { Output } \\
\text { vang Benar }\end{array}$ & $\begin{array}{l}\text { Kriteria } \\
\text { Evaluasi }\end{array}$ & Output \\
\hline $\begin{array}{c}\text { Pengujian } \\
\text { Login }\end{array}$ & 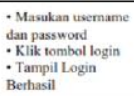 & $\begin{array}{l}\text { Username } \\
\text { dan } \\
\text { Password }\end{array}$ & $\begin{array}{c}\text { Semua } \\
\text { bethasil dan } \\
\text { tidik ada } \\
\text { errot }\end{array}$ & $\begin{array}{c}\text { Tampilan } \\
\text { setelath klik } \\
\text { login sesuai } \\
\text { prosedur }\end{array}$ & $\begin{array}{c}\text { Semua } \\
\text { sudah di } \\
\text { akses dan } \\
\text { tidak ada } \\
\text { enror }\end{array}$ \\
\hline $\begin{array}{l}\text { Cek } \\
\text { usemane } \\
\text { dan } \\
\text { password } \\
\text { (tidak } \\
\text { disi) }\end{array}$ & 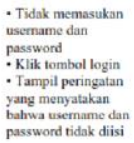 & - & $\begin{array}{c}\text { Ada } \\
\text { peringatan } \\
\text { usermanme } \\
\text { dan } \\
\text { password } \\
\text { thdak disi }\end{array}$ & 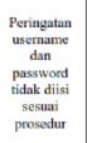 & $\begin{array}{l}\text { Peringutan } \\
\text { ussmaname } \\
\text { dan } \\
\text { password } \\
\text { tidak disis } \\
\text { sesuai } \\
\text { prosedur }\end{array}$ \\
\hline $\begin{array}{l}\text { Cek } \\
\text { usemane } \\
\text { dan } \\
\text { passorord } \\
\text { salah }\end{array}$ & $\begin{array}{l}\text { - Masukan usename } \\
\text { dan password yang } \\
\text { salah } \\
\text { Klik tombol login } \\
\text { - Tampil peringatan } \\
\text { yang menyathan } \\
\text { balwa usemane dan } \\
\text { password salah }\end{array}$ & $\begin{array}{l}\text { Usemame } \\
\text { dan } \\
\text { password }\end{array}$ & $\begin{array}{c}\text { Ada } \\
\text { peringatan } \\
\text { uermame } \\
\text { dan } \\
\text { password } \\
\text { salah }\end{array}$ & $\begin{array}{c}\text { Peringatan } \\
\text { usemane } \\
\text { dan } \\
\text { passorort } \\
\text { salah secuas } \\
\text { prosedur }\end{array}$ & $\begin{array}{c}\text { Peringatan } \\
\text { usemame } \\
\text { dan } \\
\text { password } \\
\text { salah seruai } \\
\text { prosedur }\end{array}$ \\
\hline
\end{tabular}

\subsection{Uji Manfaat}

Berikut ini adalah hasil data SPSS

Kuisioner pada uji manfaat Tabel 2. Uji Manfaat

\begin{tabular}{|c|c|c|c|c|c|c|c|c|c|c|c|c|c|}
\hline \multirow{2}{*}{ Responden } & \multicolumn{12}{|c|}{ Pertanyaan } & \multirow{2}{*}{ Total } \\
\hline & 1 & 2 & 3 & 4 & 5 & 6 & 7 & 8 & 9 & 10 & 11 | & 12 & \\
\hline 1 & 3 & 3 & 4 & 3 & 3 & 3 & 3 & 3 & 3 & 4 & 3 & 3 & 38 \\
\hline 2 & 4 & 4 & 4 & 4 & 4 & 4 & 4 & 4 & 4 & 4 & 4 & 4 & 48 \\
\hline 3 & 4 & 4 & 4 & 4 & 4 & 3 & 4 & 4 & 4 & 4 & 4 & 4 & 47 \\
\hline 4 & 4 & 4 & 4 & 4 & 4 & 4 & 3 & 4 & 3 & 4 & 4 & 4 & 46 \\
\hline 5 & 4 & 4 & 4 & 4 & 4 & 4 & 3 & 4 & 4 & 4 & 4 & 4 & 47 \\
\hline 6 & 3 & 3 & 3 & 4 & 4 & 3 & 3 & 4 & 3 & 3 & 3 & 3 & 39 \\
\hline 7 & 3 & 3 & 4 & 4 & 3 & 3 & 3 & 3 & 3 & 4 & 3 & 3 & 39 \\
\hline 8 & 4 & 3 & 4 & 4 & 4 & 4 & 4 & 4 & 4 & 4 & 4 & 4 & 47 \\
\hline 9 & 3 & 3 & 3 & 4 & 3 & 3 & 3 & 3 & 3 & 2 & 3 & 3 & 36 \\
\hline 10 & 4 & 4 & 4 & 4 & 3 & 4 & 3 & 4 & 4 & 3 & 3 & 4 & 44 \\
\hline 11 & 4 & 4 & 3 & 4 & 3 & 4 & 4 & 4 & 3 & 3 & 4 & 4 & 44 \\
\hline 12 & 4 & 4 & 3 & 4 & 4 & 3 & 4 & 3 & 3 & 4 & 4 & 4 & 44 \\
\hline 13 & 4 & 3 & 3 & 3 & 3 & 3 & 3 & 3 & 4 & 3 & 3 & 4 & 39 \\
\hline 14 & 3 & 3 & 4 & 4 & 3 & 4 & 3 & 3 & 3 & 3 & 3 & 3 & 39 \\
\hline 15 & 3 & 3 & 4 & 4 & 4 & 4 & 4 & 4 & 3 & 4 & 4 & 3 & 44 \\
\hline 16 & 4 & 3 & 3 & 4 & 3 & 3 & 3 & 4 & 4 & 3 & 3 & 4 & 41 \\
\hline 17 & 3 & 4 & 2 & 4 & 3 & 3 & 3 & 4 & 3 & 4 & 3 & 3 & 39 \\
\hline 18 & 4 & 4 & 4 & 4 & 4 & 4 & 4 & 4 & 4 & 4 & 4 & 4 & 48 \\
\hline 19 & 4 & 4 & 3 & 4 & 4 & 3 & 4 & 3 & 4 & 3 & 4 & 4 & 44 \\
\hline 20 & 3 & 4 & 3 & 4 & 3 & 3 & 4 & 4 & 4 & 3 & 4 & 3 & 42 \\
\hline 21 & 3 & 4 & 4 & 4 & 4 & 3 & 4 & 4 & 4 & 4 & 4 & 3 & 45 \\
\hline 22 & 4 & 4 & 3 & 4 & 3 & 3 & 4 & 4 & 4 & 3 & 4 & 4 & 44 \\
\hline 23 & 3 & 3 & 4 & 4 & 3 & 4 & 4 & 4 & 3 & 4 & 4 & 3 & 43 \\
\hline 24 & 4 & 3 & 4 & 4 & 4 & 4 & 3 & 4 & 4 & 4 & 3 & 4 & 45 \\
\hline 25 & 4 & 4 & 3 & 4 & 3 & 3 & 3 & 3 & 3 & 3 & 3 & 4 & 40 \\
\hline 26 & 4 & 4 & 3 & 4 & 4 & 4 & 4 & 4 & 4 & 4 & 4 & 4 & 47 \\
\hline 27 & 4 & 4 & 4 & 4 & 3 & 4 & 4 & 4 & 4 & 4 & 4 & 4 & 47 \\
\hline 28 & 4 & 3 & 4 & 4 & 4 & 4 & 3 & 4 & 4 & 4 & 3 & 4 & 45 \\
\hline 29 & 4 & 4 & 4 & 4 & 3 & 3 & 4 & 3 & 4 & 4 & 4 & 4 & 45 \\
\hline 30 & 4 & 4 & 3 & 4 & 4 & 4 & 4 & 4 & 4 & 4 & 4 & 4 & 47 \\
\hline
\end{tabular}

4.4 Intepretasi Hasil

\begin{tabular}{|l|l|l|l|}
\hline $\begin{array}{l}\text { Ussab } \\
\text { ility }\end{array}$ & $\begin{array}{l}\text { Learna } \\
\text { bility }\end{array}$ & $\begin{array}{l}\text { Effici } \\
\text { ency }\end{array}$ & $\begin{array}{l}\text { Accepta } \\
\text { bility }\end{array}$ \\
\hline $98,9 \%$ & $100 \%$ & $100 \%$ & $99,2 \%$ \\
\hline
\end{tabular}

Tabel 3. Rata-rata Hasil Uji Manfaat

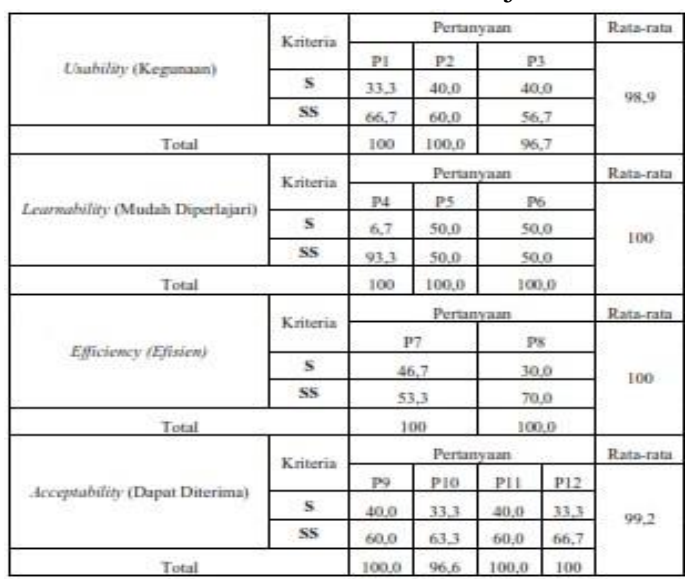

\section{KESIMPULAN}

Sistem Informasi Pelayanan Administrasi Surat Pengantar Berbasis Website Dengan Framework Codeigniter Guna Meningkatkan Kualitas Pelayanan Pada Desa Tambaksari Kidul Kabupaten Banyumas diperoleh kesimpulan yaitu pada pengujian hipotesis, sistem ini dapat memberikan pengaruh yang signifikan terhadap proses pembuatan surat pengantar sehingga menjadi lebih cepat dibandingkan dengan sebelum menggunakan sistem. Hal ini dibuktikan dengan hasil pengujian hipotesis yang nilai Sig. 0,378 atau lebih besar dari 0,05 yang berarti H1 dapat diterima. Waktu yang diperlukan sebelum menggunakan sistem memiliki waktu rata - rata yaitu 152,38 menit kemudian setelah menggunakan sistem memiliki waktu ratarata menjadi 12,01 menit. Sistem ini dapat juga dapat dikatakan dapat meningkatkan efektifitas proses pembuatan surat pengantar di desa Tambaksari Kidul.

\section{SARAN}

Saran yang dapat diberikan oleh peneliti untuk pengembangan selanjutnya yaitu : 
1. Pengembangan sistem selanjutnya bisa menggunakan sistem website dengan framework Laravel.

2. Pengembangan sistem selanjutnya dapat meningkatkan keamanan website yaitu menambahkan fungsi enkripsi seperti Hash pada bagian hasil surat pengantar.

3. Pengembangan sistem selanjutnya jika ingin mengembangkan di platform mobile, pastikan membangun sistem sesuai dengan fitur yang di butuhkan warga. Misalnya seperti fungsi informasi desa, sehingga pada saat warga mendownload app mobile tidak hanya di pakai sekali saja lalu di uninstal.

\section{DAFTAR PUSTAKA}

[1] Zainudin, A. (2016). Model Kelembagaan Pemerintah. Kajian Ilmu Pemerintah dan Politik Daerah.

[2] Rozi, F., \& Listiawan, T. (2007). Pengembangan Website dan Sistem Indormasi Desa Di Kabupaten Tulungagung. JIPI (Jurnal Ilmiah Penelitian dan Pengembangan Informatika).

[3] Bintaro, R. (1986). Desa -Kota, Bandung : Ghalia Indonesia

[4] Thomas Wijaya (1992). Koresponden bisnis : bentuk dan bahasan surat, bagian jenis surat, contoh aneka surat.

[5] Iksanudin, M. S. (2018). Mengusasai Framework Symfony.

[6] Rossa, \& Shalahuddin, M. (2016). Rekayasa Perangkat Lunak Terstruktur dan Berorientasi Objek. Bandung : Informatika
[7] Setyawati, E., Sarwani, Wijoyo, H., \& Soeharmoko, N. (2020). Relational Database Management System (RDBMS). Banyumas: CV. Pena Persada.

[8] Wijoyo, H. (2020). Analisis Pengendalian Internal Dalam Pemberian Kredit Pada PT Bank Perkreditan Rakyat (BPR) Indomitra Mandiri. TIN: Terapan Informatika Nusantara, 1(4), 157-162.

[9] Wijoyo, H., \& Marpaung, S. L. (2020). The Influence of Quality Information and Reputation Of TIX ID Application Toward the Interest of Purchase Tickets Online in XXI Cinema Ciputra Seraya Mall Pekanbaru City. Jurnal Suluh Pendidikan, 8(2), 9-21.

[10] Yahya, M., \& Wijoyo, H. (2020). Developing School Information Program: Integrated Management System based on Character Value at SMP Negeri 9 Tapung. International Journal of Asian Education, 1(3), 179-186.

[11] ijoyo, H. (2020). RANCANG BANGUN SISTEM INFORMASI PENGGAJIAN DAN ABSENSI KARYAWAN MEGARA HOTEL PEKANBARU BERBASIS WEB. Ekonam: Jurnal Ekonomi, Akuntansi \& Manajemen, 2(2), 5676. 